DOI: $10.1080 / 02652030412331272467$

\title{
Structure elucidation of sildenafil analogues in herbal products
}

\author{
Authors: L. Blok-Tip ${ }^{\text {a }}$; B. Zomer ${ }^{\text {b }}$; F. Bakker ${ }^{\text {a }}$; K. D. Hartog ${ }^{a}$; M. Hamzink ${ }^{\text {}}$; J. ten \\ Hove $^{b}$; M. Vredenbregt ${ }^{b}$; D. de Kaste ${ }^{a}$ \\ Affiliations: \\ a KCF (Centre for Quality of Chemical-Pharmaceutical Products), RIVM (National Institute for \\ Public Health and the Environment). NL-3720 BA Bilthoven. The Netherlands \\ b LAC (Laboratory for Analytical Chemistry), RIVM (National Institute for Public Health and \\ the Environment). NL-3720 BA Bilthoven. The Netherlands
}

\begin{abstract}
The structure of unknown compounds present in herbal products was elucidated using liquid chromatography-electrospray ionization-mass spectrometry, direct-infusion electrospray ionization-mass spectrometry, and nuclear magnetic resonance. Compounds 1-3 were identified as sildenafil analogues, 1 bearing an $\mathrm{N}$-ethylpiperazine moiety instead of an $\mathrm{N}$ methylpiperazine, and an acetyl group instead of the sulfonyl group, named acetildenafil, 2 bearing an $\mathrm{N}$-ethylpiperazine moiety instead of an $\mathrm{N}$-methylpiperazine (homosildenafil), and $\mathbf{3}$ bearing an $\mathrm{N}$-hydroxylethylpiperazine moiety instead of an $\mathrm{N}$-methylpiperazine, named hydroxyhomosildenafil. When analysing products marketed for penile erectile dysfunction or marketed as aphrodisiacs, attention should be given to the possible presence of these components.
\end{abstract}

\section{Introduction}

Sildenafil is the active compound in Viagra®, a prescription medicine for penile erectile dysfunction. However, it is also found in aphrodisiacs, mainly advertised as natural products. As aphrodisiacs and natural products increase in popularity, especially via the World Wide Web, this will be a global problem: consumers are not aware of taking a prescription drug that has contraindications.

Recently, the present authors identified three sildenafil analogues in three different herbal products. A completely new analogue 1, named acetildenafil, was identified in product $\mathbf{A}$, oral capsules, advertised as 'a firm erection of Mother Nature', based on traditional Chinese medicine. Homosildenafil (2) was identified in product B, Chinese oral tablets, labelled as a herbal preparation containing Juglans regia (walnut), to be used as an anti-fatigue agent according to the package leaflet. However, it was sold as herbal Viagra. Shin et al. (2003) published the structure of this analogue using nuclear magnetic resonance (NMR) spectroscopy. The compound was discovered in a beverage marketed for erectile dysfunction. Hydroxyhomosildenafil (3) was identified in product $\mathbf{C}$, Chinese oral capsules, advertised as an herbal alternative for Viagra.

Based on the structural analogy of these three compounds with sildenafil, similar biological activity is to be expected. Pfizer (unpublished data) reported limited pharmacological data for hydroxyhomosildenafil, demonstrating biological activity comparable with sildenafil. In Japan, one case of liver function impairment was reported that might be due to the use of a product containing hydroxyhomosildenafil (Japan, Pharmaceutical and Food Safety Bureau - Health, Labor, and Welfare Ministry 2004). Beside this limited information, no data on toxicology and efficacy are described in the public (medical) literature for these three analogues. It seems there is a tendency towards the development of designer drugs based on sildenafil that might present a risk for human health. 
This paper describes the elucidation of these three compounds using liquid chromatographyelectrospray ionization-mass spectrometry $\left(\right.$ LC-ESI-MS $\left.{ }^{n}\right)$, direct-infusion ESI-MS ${ }^{n}$, and ${ }^{1} \mathrm{H}-$ and ${ }^{13} \mathrm{C}-\mathrm{NMR}$.

\section{Materials and methods}

\section{Samples}

Product $\mathrm{A}$ and $\mathrm{C}$ were submitted by the Dutch Food and Consumer Product Safety Authority for analysis on phosphodiesterase type 5 enzyme (PDE5) inhibitors. Product B was submitted by the Dutch Health Care Inspectorate for analysis on sildenafil.

\section{Materials for LC-ESI-MS ${ }^{n}$ and direct-infusion ESI-MS ${ }^{n}$}

Sildenafil citrate (pharmaceutical quality) was obtained from Pfizer, Inc. (Groton, USA). Tablets of Cialis $\AA$, containing $20 \mathrm{mg}$ tadalafil per tablet, were obtained from Eli Lilly Nederland B.V. (Houten, The Netherlands). Tablets of Levitra ${ }^{\circledR}$, containing $20 \mathrm{mg}$ vardenafil per tablet, were obtained from Bayer AG (Leverkussen, Germany). Methanol (highperformance liquid chromatography grade; $\mathrm{MeOH}$ ) was obtained from Promochem (Wesel, Germany). Formic acid (p.A.) was obtained from Merck (Darmstadt, Germany). Ammonium hydroxide $\left(\mathrm{NH}_{4} \mathrm{OH}\right)$ was obtained from two suppliers: Merck (32\%, extra pure) and Acros Organics (Geel, Belgium) (reagent ACS), being of comparable quality. Water was demineralized and filtered using a Millipak ${ }^{\circledR} 200$ 0.22- $\mu \mathrm{m}$ filter from Millipore B.V. (Amsterdam, The Netherlands). Acidified water was prepared by addition of $2 \mathrm{ml}$ formic acid to $1000 \mathrm{ml}$ water and adjusting the $\mathrm{pH}$ to 4.0 using $\mathrm{NH}_{4} \mathrm{OH}$.

\section{Materials for NMR}

Solvents and chemicals for NMR analysis - acetone, acetone- $d_{6}$, acetonitrile (ACN), chloroform $\left(\mathrm{CHCl}_{3}\right)$, deuterated chloroform $\left(\mathrm{CDCl}_{3}\right)$, deuterium oxide $\left(\mathrm{D}_{2} \mathrm{O}\right)$, dimethylsulfoxide (DMSO), $\mathrm{MeOH}$, hydrochloric acid $(\mathrm{HCl}), \mathrm{C}_{18}$ material for reversed-phase liquid chromatography, sodium hydroxide $(\mathrm{NaOH})$, sodium sulphate $\left(\mathrm{Na}_{2} \mathrm{SO}_{4}\right)$, trimethylsilyl- $d_{4}{ }^{-}$ propanoic acid, sodium salt (TMSP) - were obtained from commercial sources in the best possible quality.

\section{Materials for (IR)}

Potassium bromide (KBr) powder, spectroscopic grade, used for IR analysis was supplied by Anadis Instruments B.V. (Malden, The Netherlands).

\section{Instrumentation}

Direct-infusion ESI-MS ${ }^{n}$ experiments were carried out using an LCQ Advantage ion-trap mass spectrometer equipped with an ESI interface, operated by Xcalibur software version 3.1, from Thermo Finnigan B.V. (Breda, The Netherlands). For LC-ESI-MS ${ }^{n}$ experiments, an LC system, consisting of a Surveyor autosampler, LC pump and photodiode array (PDA) detector (all Thermo Finnigan B.V.), was connected to the mass spectrometer.

\footnotetext{
${ }^{1} \mathrm{H}-,{ }^{13} \mathrm{C}$-, and two-dimensional NMR data were recorded on a JEOL Eclipse 400 spectrometer.
}

IR spectroscopy was performed on a Bruker IFS55 FT-IR spectrometer with a DTGS detector and OPUS software version 4.0. 


\section{Methods}

\section{Preparation of standard and sample solutions}

A standard stock solution was prepared for LC-MS ${ }^{n}$ analysis on sildenafil by dissolving sildenafil citrate in $\mathrm{MeOH}$ at a concentration of about $450 \mathrm{~g} \mathrm{ml}^{-1}$ equivalent to approximately $325 \mu \mathrm{g}$ sildenafil $\mathrm{ml}^{-1}$. The working solution was prepared by diluting the stock solution with mobile phase to about $6.5 \mathrm{\mu g} \mathrm{ml}^{-1}$ sildenafil. Tablets of Cialis $\AA$ were ground, tablet powder was dissolved in $\mathrm{MeOH}$ and diluted with mobile phase to about $2 \mathrm{\mu g} \mathrm{m}^{-1}$ tadalafil. Similarly, a solution of about $2 \mathrm{\mu g} \mathrm{ml}^{-1}$ vardenafil was prepared from tablets of Levitra $\AA$.

\section{Sample $\boldsymbol{A}$}

For direct-infusion ESI-MS ${ }^{n}$, the content of four capsules was homogenized and approximately $380 \mathrm{mg}$ were dissolved in $100 \mathrm{ml} \mathrm{MeOH}$ by sonification. After filtration over a $0.45-\mu \mathrm{m}$ filter, the solution was diluted 1:10 with mobile phase. This solution was also diluted $1: 10$ with mobile phase for LC-MS ${ }^{n}$ analysis. For NMR analysis, the compound of interest was isolated by dissolving the content of one capsule, approximately $100 \mathrm{mg}$, in $1 \mathrm{ml}$ DMSO : water $(20: 80 \mathrm{v} / \mathrm{v})$. The product was isolated by reversed-phase liquid chromatography on $\mathrm{C}_{18}$ material, washing with $10 \mathrm{ml}$ water, followed by $10-\mathrm{ml}$ mixtures of methanol and water with increasing amounts of methanol ( $\mathrm{v} / \mathrm{v} 10,40,60$ and $90 \%)$. The compound was eluted from the column with $10 \mathrm{ml} \mathrm{ACN:0.5} \mathrm{M} \mathrm{HCl}(10: 90 \mathrm{v} / \mathrm{v})$. The fractions containing the product were pooled and evaporated to dryness under a stream of nitrogen. The residue was dissolved in 2 $\mathrm{ml}$ water, basified using $1 \mathrm{M} \mathrm{NaOH}$ solution and extracted with $\mathrm{CHCl}_{3}$. The organic layer was washed with water, dried over $\mathrm{Na}_{2} \mathrm{SO}_{4}$ and evaporated yielding a white solid. The solid was dissolved in $\mathrm{CDCl}_{3}$ for NMR analysis. For IR analysis, the solvent was evaporated and the residue prepared as for the $\mathrm{KBr}$ tablet.

\section{Sample $B$}

For LC-MS ${ }^{n}$ analysis, one tablet was ground and about 50 mg were dissolved in $25 \mathrm{ml} \mathrm{MeOH}$ by sonification. After filtration over a $0.45-\mu \mathrm{m}$ filter, the solution was diluted 1:200 with mobile phase. For NMR analysis, the compound of interest was isolated by extracting one ground tablet three times with $5 \mathrm{ml}$ acetone followed by three times with $5 \mathrm{ml}$ water. The water layer was basified using $5 \mathrm{M} \mathrm{NaOH}$ solution and extracted three times with $10 \mathrm{ml} \mathrm{CHCl}_{3}$. The organic layers were combined, dried with $\mathrm{Na}_{2} \mathrm{SO}_{4}$, filtered and evaporated to dryness under a stream of nitrogen. The residue was dissolved in approximately $0.8 \mathrm{ml} \mathrm{CDCl}$.

\section{Sample $C$}

For direct-infusion ESI-MS ${ }^{n}$, the content of three capsules was homogenized and approximately $210 \mathrm{mg}$ were dissolved in $50 \mathrm{ml} \mathrm{MeOH}$ by sonification. After filtration over a $0.45-\mu \mathrm{m}$ filter, the solution was diluted 1:10 with mobile phase. This solution was also diluted $1: 10$ with mobile phase for LC-MS ${ }^{n}$ analysis. For qualitative NMR analysis, the compound of interest was isolated by extraction of $500 \mathrm{mg}$ sample using acetone and water, and acid/base separation as described for sample A. For quantitative NMR analysis, $25 \mathrm{mg}$ were dissolved in $0.7 \mathrm{ml} \mathrm{D} \mathrm{D}_{2} \mathrm{O}$ containing $0.075 \%$ TMSP as internal standard and $0.7 \mathrm{ml}$ acetone- $d_{6}$.

\section{LC-ESI-MS $^{n}$ and direct-infusion ESI-MS ${ }^{n}$}

For chromatographic separation and ultraviolet light detection, the following conditions were used: XTerra $\mathrm{MS} \mathrm{C}_{18}$ guard column $(20 \times 2.1 \mathrm{~mm}, 3.5 \mu \mathrm{m})$ and $\mathrm{XTerra} \mathrm{MS} \circledast \mathrm{C}_{18}$ analytical column (100 × $2.1 \mathrm{~mm}, 3.5 \mu \mathrm{m}$; Waters Chromatography B.V., Etten-Leur, The Netherlands): isocratic elution using $\mathrm{MeOH}$ : acidified water (50:50 v/v); flow rate at $0.25 \mathrm{ml} \mathrm{min}^{-1}$; column temperature of $25^{\circ} \mathrm{C}$; injection volume of $20 \mu$; ultraviolet light detection from 200 to $350 \mathrm{~nm}$. Mass spectrometry was carried out in positive-ion mode using the ESI interface. Nitrogen was used as sheath gas (20 arbitrary units) and as auxiliary gas (10 arbitrary units). Source settings used: ion spray voltage $5.0 \mathrm{kV}$, capillary temperature $300^{\circ} \mathrm{C}$, capillary voltage $31 \mathrm{~V}$, 
tube lens offset $55 \mathrm{~V} . \mathrm{MS}^{1}$ : mass range $\mathrm{m} / z=80-1000 . \mathrm{MS}^{\mathrm{n}}$ : relevant ions selected and fragmented using a collision energy of 40.00 arbitrary units. Instrument conditions were checked using sildenafil citrate standard working solution. Samples $\mathbf{A}$ and $\mathbf{C}$ were analysed for PDE5 inhibitors; sample B was analysed for sildenafil only, using a standard analytical method (Bakker et al. 2004).

NMR spectra were recorded using standard single and multipulse sequences for one- and two-dimensional NMR spectra. FIDs were zero-filled, apodized using exponential (single pulse) or sinebell (multipulse) functions, phase and baseline corrected, and scaled against the residual $\mathrm{CHCl}_{3}$ signal at $7.26\left({ }^{1} \mathrm{H}\right)$ or $77.0 \mathrm{ppm}\left({ }^{13} \mathrm{C}\right)$.

IR measurements were carried out over the spectral range $4000-400 \mathrm{~cm}^{-1}$ with an optical resolution of $2 \mathrm{~cm}^{-1}$, and 32 scans were co-added.

\section{Results and discussion}

\section{Sample A, compound 1}

Based on LC-ESI-MS ${ }^{n}$, direct-infusion ESI-MS ${ }^{n},{ }^{1} \mathrm{H}$ - and ${ }^{13} \mathrm{C}-\mathrm{NMR}$, and IR data, the compound was identified as a sildenafil analogue bearing an $\mathrm{N}$-ethylpiperazine moiety in stead of an $\mathrm{N}$-methylpiperazine, and an acetyl group instead of the sulfonyl group (figure 1).

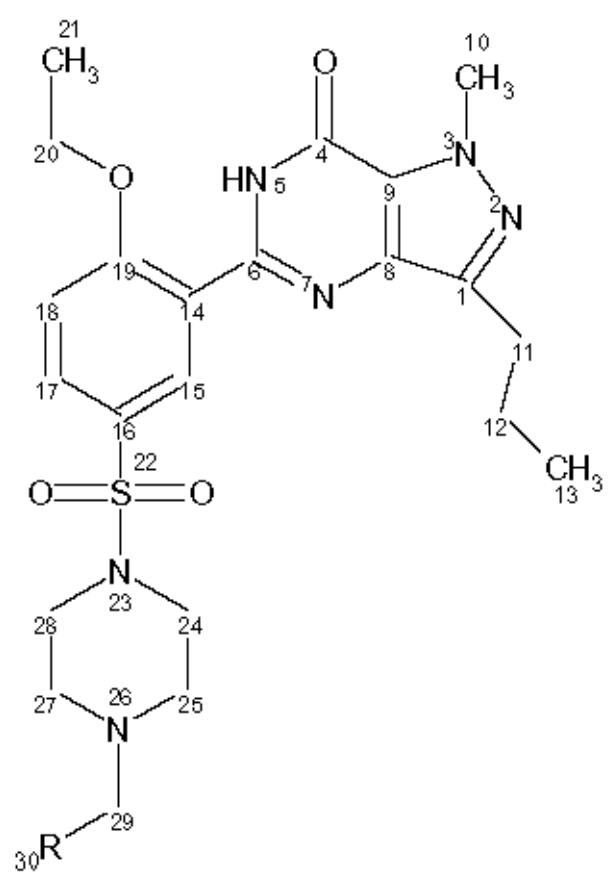

sildenafil, homosildenafil (2), and<smiles>[R]CN1CCN(CC(=O)c2ccc(OCC)c(-c3nc4c(I=CC)nn(C)c4c(=O)[nH]3)c2)CC1</smiles>

acetildenafil (1)

\section{hydroxyhomosildenafil (3)}

Figure 1. Structures of sildenafil (1) and analogues homosildenafil (2) and hydroxyhomosildenafil (3). Structures: sildenafil (1), (1-[[3-(6,7-dihydro-1-methyl-7-oxo-3propyl-1H-pyrazolo[4,3-d]pyrimidin-5-yl)-4-ethoxyphenyl]-sulfonyl]-4-methylpiperazine) $R=H$; 2, (1-[[3-(6,7-dihydro-1-methyl-7-oxo-3-propyl-1H-pyrazolo[4,3-d]pyrimidin-5-yl)-4ethoxyphenyl]-sulfonyl]-4-ethylpiperazine) $\mathrm{R}=\mathrm{CH}_{3} ; 3$, (1-[[3-(6,7-dihydro-1-methyl-7-oxo-3propyl-1H-pyrazolo [4,3-d]pyrimidin-5-yl)-4-ethoxyphenyl]-sulfonyl]-4-(2-hydroxyethyl)piperazine) $\mathrm{R}=\mathrm{CH}_{2} \mathrm{OH}$; acetildenafil (1), (1-[[3-(6,7-dihydro-1-methyl-7-oxo-3-propyl-1Hpyrazolo[4,3-d]pyrimidin-5-yl)-4-ethoxyphenyl]-acetyl]-4-ethylpiperazine) $\mathrm{R}=\mathrm{CH}_{3}$. 
Sample A was analysed for PDE5 inhibitors. Although sildenafil, vardenafil and tadalafil are absent, an abundant peak at a retention time of 0.8 relative to sildenafil is observed as well in the total scan chromatogram of the PDA as in the total ion current (TIC) chromatogram of the MS detector. The UV spectrum is very different from sildenafil, vardenafil and tadalafil (table 1 ); the most abundant peak in the $\mathrm{MS}^{1}$ spectrum at that retention time is at $\mathrm{m} / \mathrm{z}=467$, accompanied with a peak at $\mathrm{m} / \mathrm{z}=489$, indicating the ions $[\mathrm{M}+\mathrm{H}]^{+}$and $[\mathrm{M}+\mathrm{Na}]^{+}$for a compound with a molecular mass of 466 . Direct-infusion ESI-MS ${ }^{2}$ showed that the fragmentation pattern of $\mathrm{m} / z 467$ is very different from the patterns of $[\mathrm{M}+\mathrm{H}]^{+}$of sildenafil, vardenafil or tadalafil (Bakker et al. 2004). The ions $\mathrm{m} / z=311$ and 313 are observed in the mass spectrum of $[\mathrm{M}+\mathrm{H}]^{+}$of both $\mathbf{1}$ and sildenafil, but the relative intensities are less than $5 \%$ for both ions in 1 compared with 100 respectively $60 \%$ in sildenafil (figure $2 a, b$ ).

Table 1. Retention time (RRT, based on the photo diode array signal) and ultraviolet light (UV) maxima of sildenafil, vardenafil, tadalafil and compounds 1-3. Compound (product)
RRT (min)
$\mathrm{UV}_{\max }(\mathrm{nm})$

tMaximum at $292 \mathrm{~nm}$ is absent; curving at $246 \mathrm{~nm}$.

Sildenafil (Viagra $\left.\AA^{\circledR}\right)$

Vardenafil (Levitra $\left.\AA^{\circledR}\right)$

Tadalafil (Cialis $\AA)$

1 Product $A$

2 Product $B$

3 Product $C$
1.0

1.2

1.5

0.8

1.0

1.0
230.292

230

230, 283

234, 279

230, 292

230, 292 
Food Additives \& Contaminants, Volume 21, Issue 8 August 2004 , pages 737 - 748

(a) Sibenafil citraat \#251-312 RT:7.25-8.32 AV:21 NL·7.41E5

F: + cESI Full ms2 475.50@40.00 [130.00-500.00]

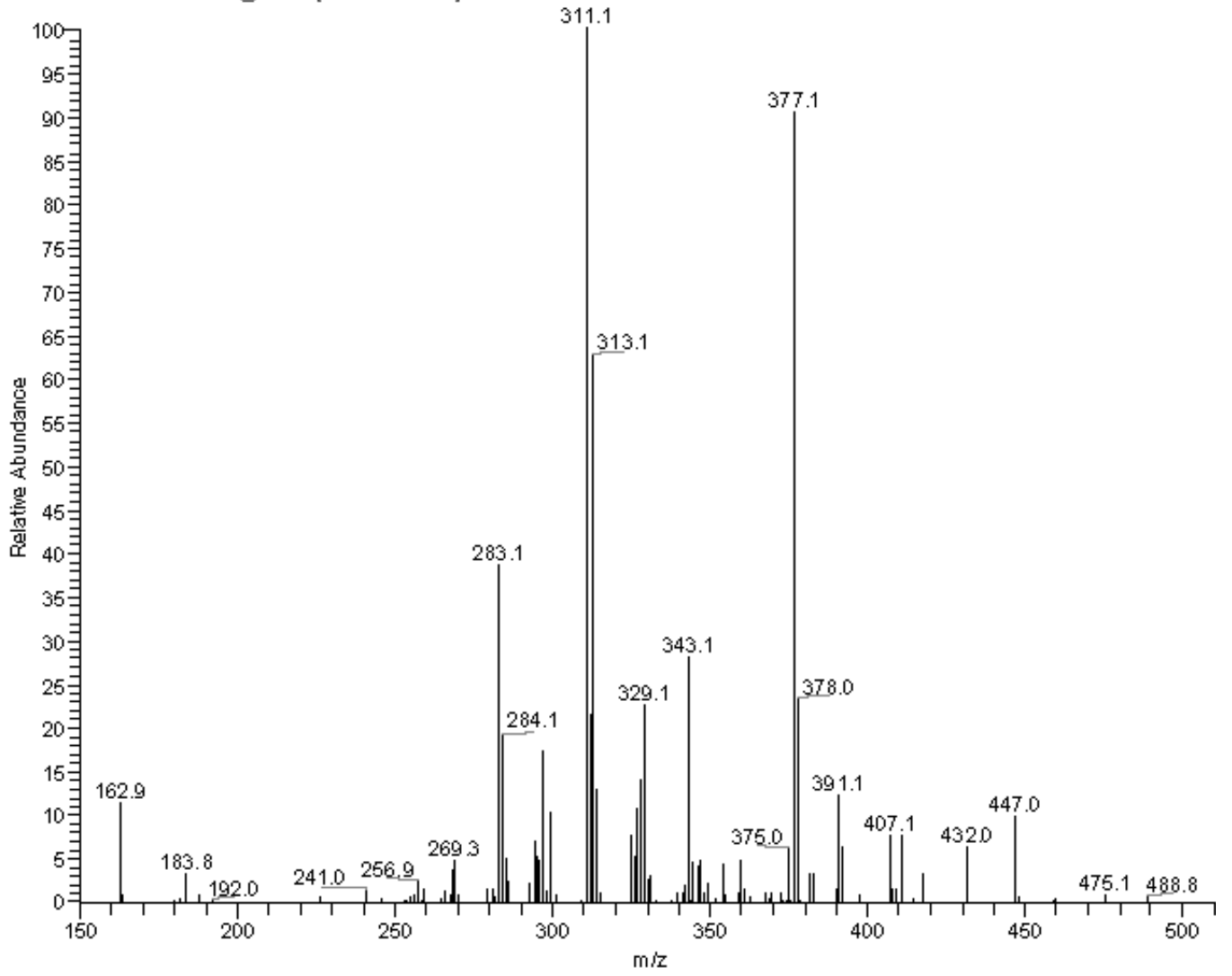

(b) Order7321_01\#190-262 RT: $5.36-6.46$ AV: 37 NL: 3.28E6

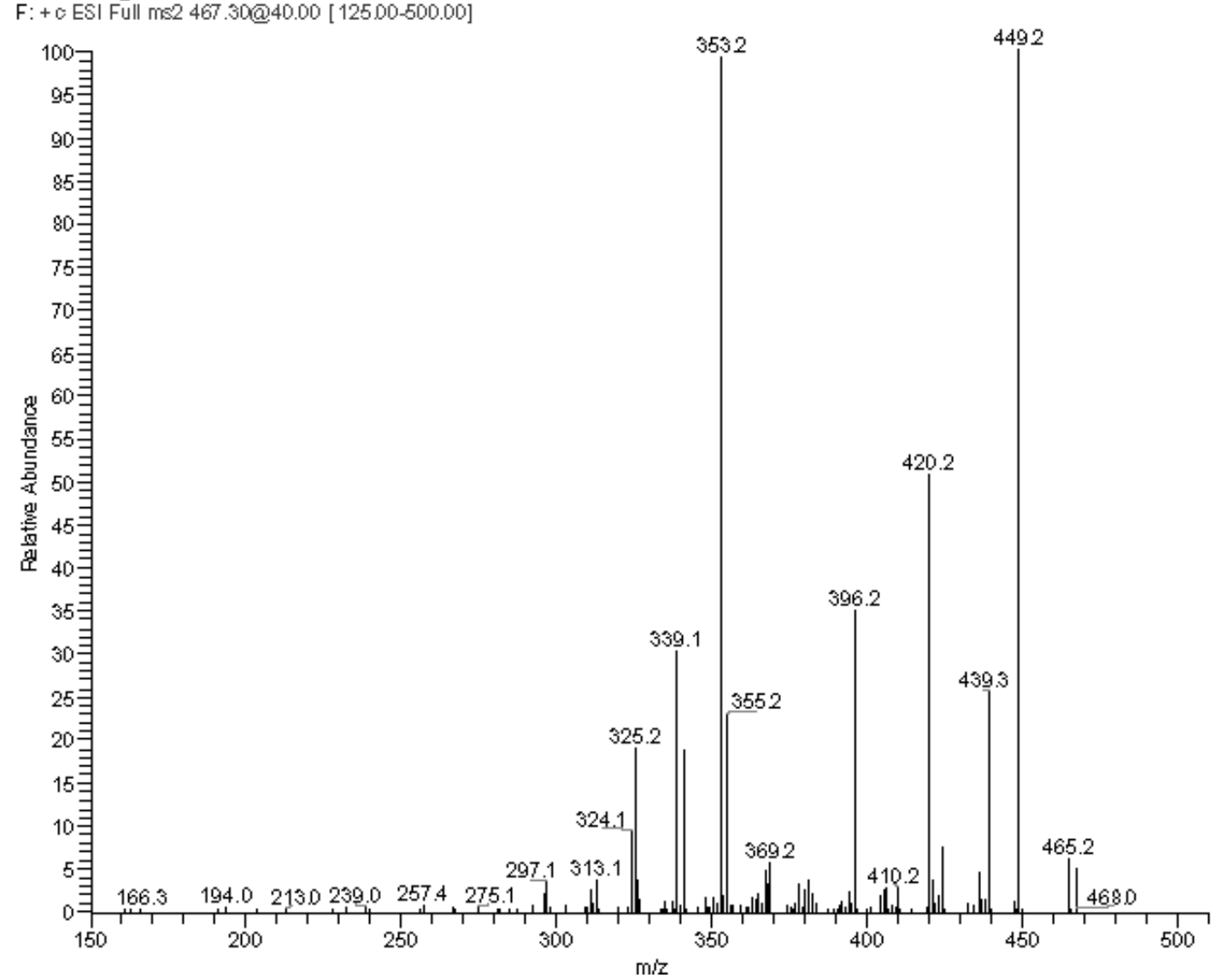


Food Additives \& Contaminants, Volume 21, Issue 8 August 2004 , pages 737 - 748

(c) Onder6893 2 \#265-334 RT: 7.23-8.28 AV: 23 NL: $1.41 \mathrm{E7}$

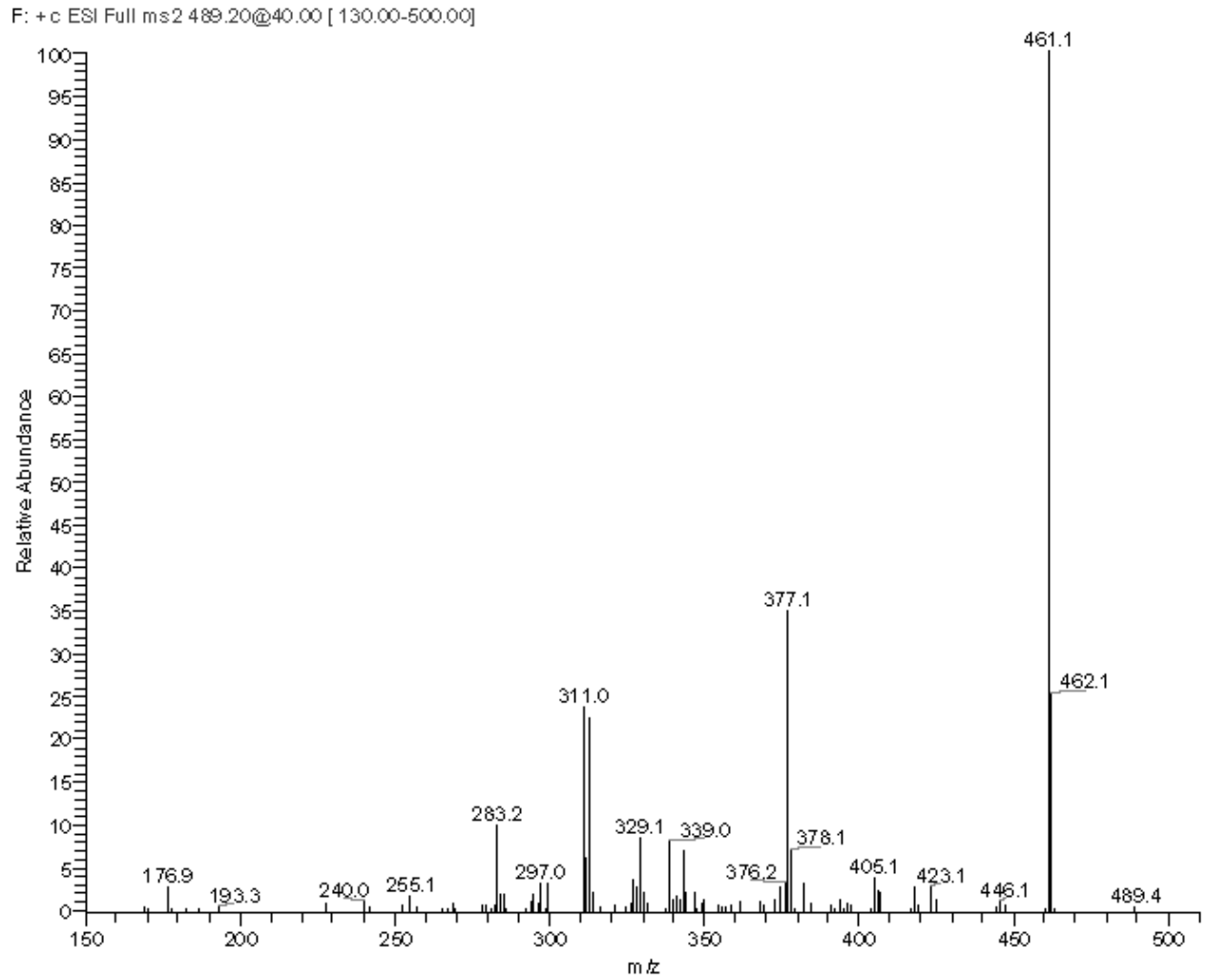

(d) Satbo02 \#233 209 RT: $6.79-7.82 \quad \mathrm{AN}: 22 \mathrm{NL}: 120 \mathrm{E} 6$

$F:+c$ ESI Full ms2 505,00@4000 [135,00-500,00]

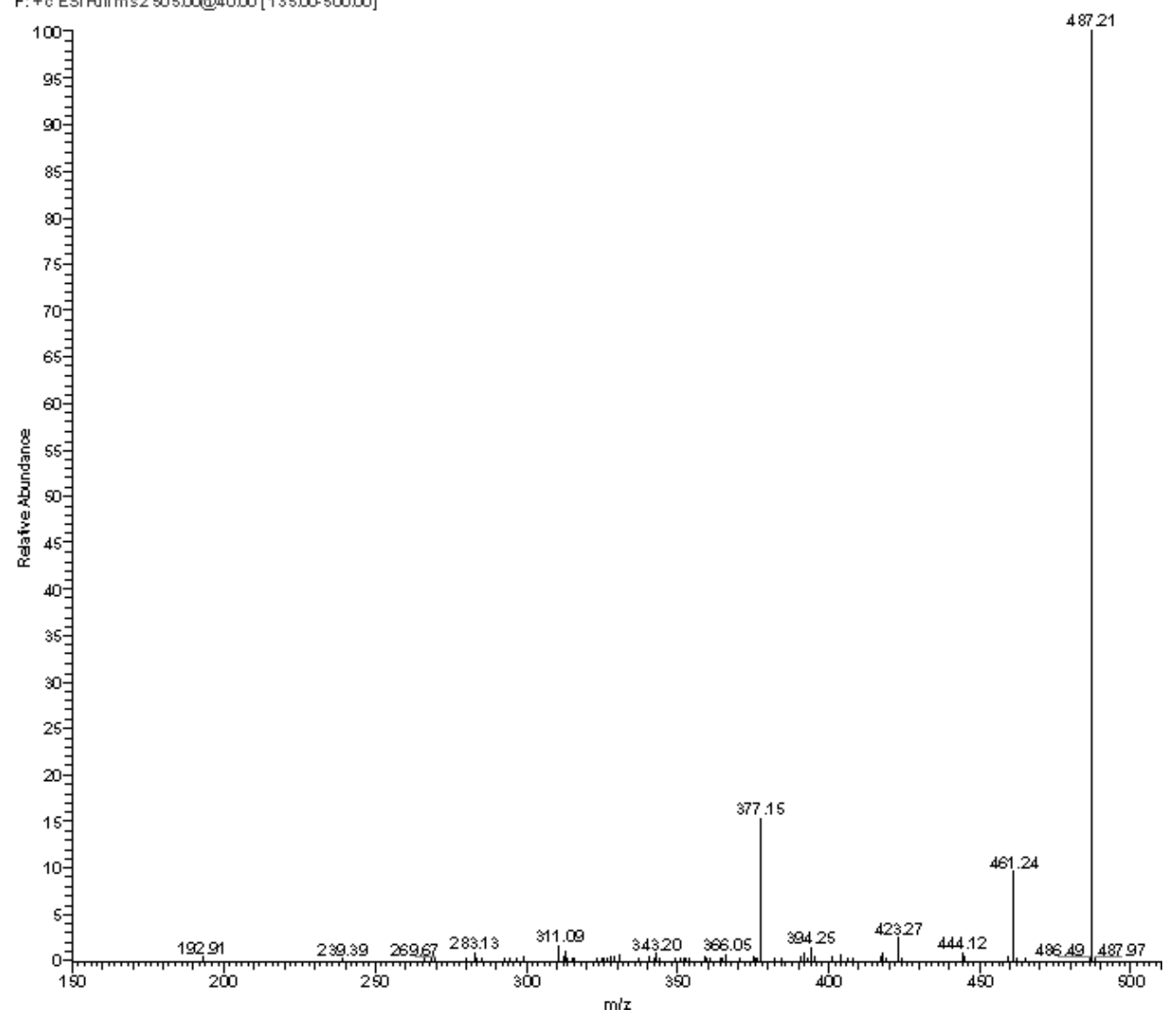


Food Additives \& Contaminants, Volume 21, Issue 8 August 2004 , pages 737 - 748

(e) Silderafil citraat \#251-312 RT: 7.26-8.26 AV: 20 NL: $1.60 E 5$ F: +c ESI Full ms3 475.40@40.00 377.20@40.00 [ 130.00-500.00]

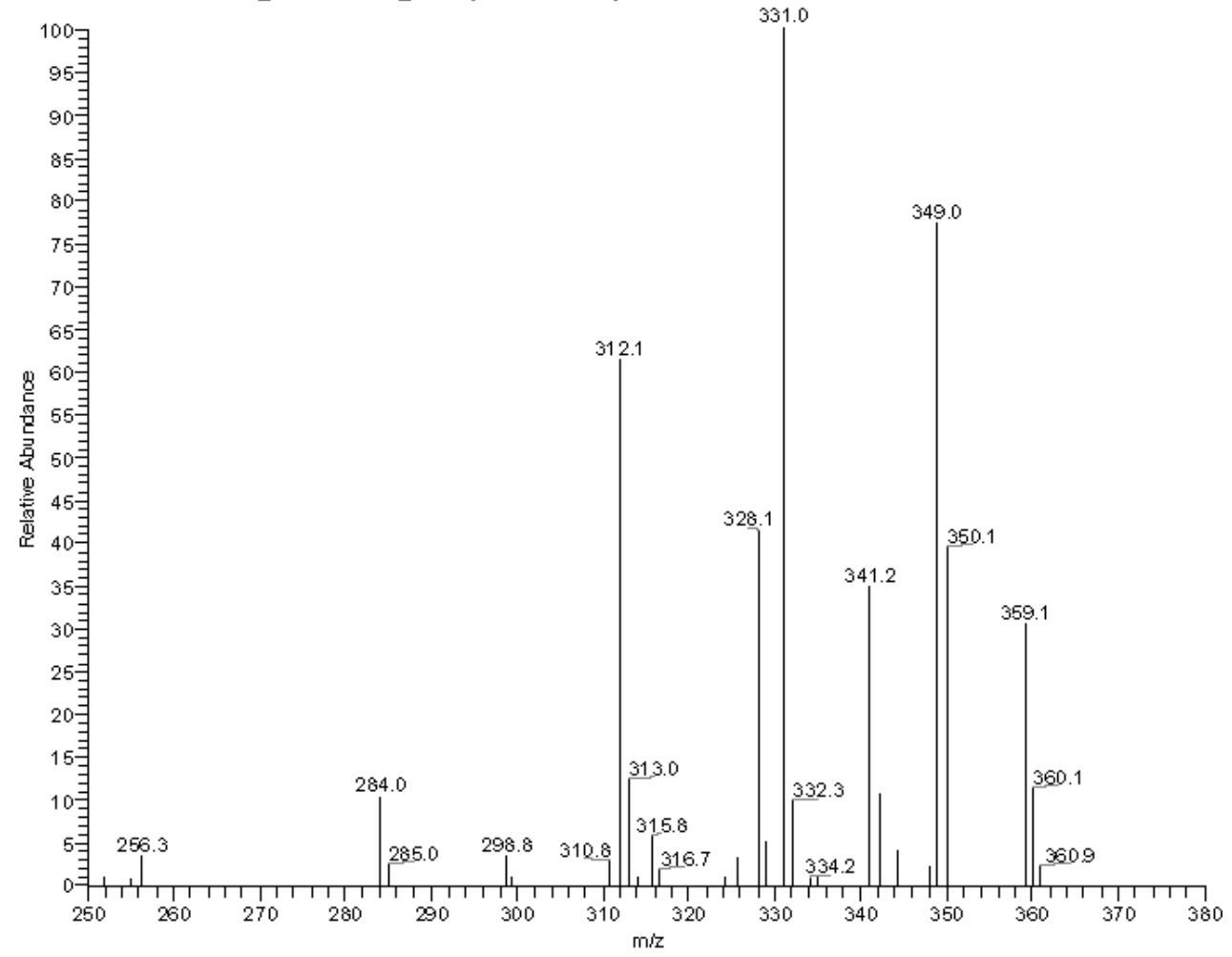

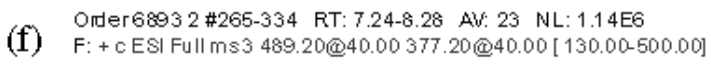

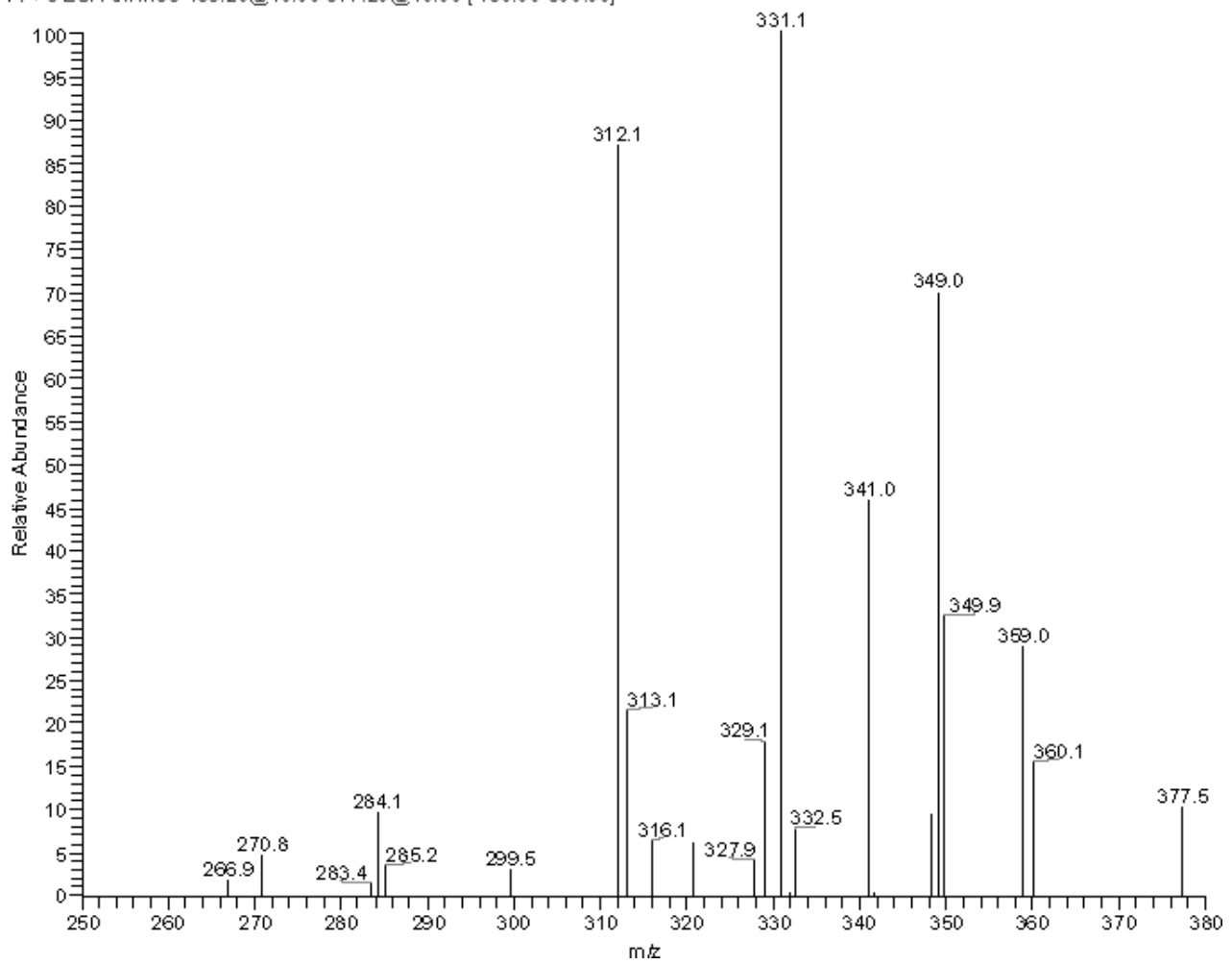


(g) Salbo02 *233-299 RT:6.80-7 83 $\quad$ RV:22 NL:3.49E4

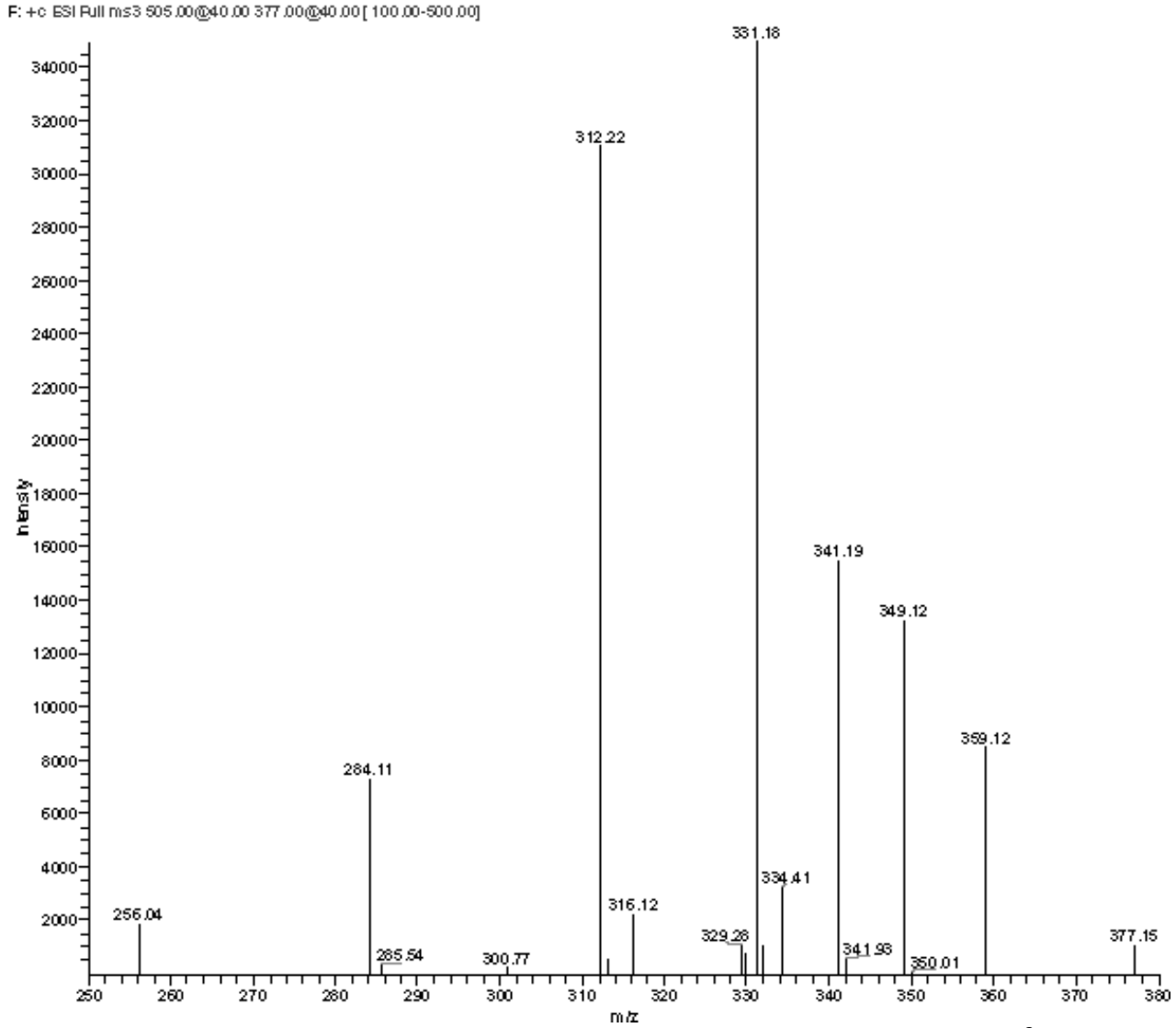

Figure 2. $M S^{n}$ spectra of sildenafil standard and of unknown compounds: (a) $M S^{2}$ spectrum of $[M+H]^{+}=475$ of sildenafil, (b) $M S^{2}$ spectrum of $[M+H]^{+}=467$ of 1 in Product $A$, (c) $M S^{2}$ spectrum of $[M+H]^{+}=489$ of 2 in Product $B$, (d) $M S^{2}$ spectrum of $[M+H]^{+}=505$ of 3 in Product $C$, (e) $M S^{3}$ spectrum of $\mathrm{m} / \mathrm{z}=475 \rightarrow 377$ of sildenafil, $(\mathrm{f}) \mathrm{MS}^{3}$ spectrum of $\mathrm{m} / \mathrm{z}=489$ $\rightarrow 377$ of 2 in Product B, $(\mathrm{g}) \mathrm{MS}^{4}$ spectrum of $\mathrm{m} / \mathrm{z}=505 \rightarrow 489 \rightarrow 377$ of 3 in Product $C$.

The difference in fragmentation behaviour can be explained by the results from the ${ }^{1} \mathrm{H}$ - and ${ }^{13} \mathrm{C}$-NMR data (table 2). The ${ }^{1} \mathrm{H}$-NMR spectrum (figure 3a) shows an amide proton at 10.8 $\mathrm{ppm}$, three aromatic protons at $9.14,8.15$ and $7.09 \mathrm{ppm}$ with a coupling pattern characteristic for a 1,2,4-substituted aromatic ring. Compared with sildenafil (table 3) (Badwan et al. 2001), the proton signals for $\mathrm{H} 15$ and $\mathrm{H} 17$ are shifted towards lower field consistent with a carbonyl group substituting the sulfonyl moiety. The $N$-methyl, $O$-ethyl and $C$-propyl groups give signals at the same field as sildenafil. The $N$-ethyl substituent shows signals at 1.05 and 2.41 $\mathrm{ppm}$. The C23 methylene group gives a singlet at $3.82 \mathrm{ppm}$. Broad peaks at 2.54 and 2.68 could be assigned to the piperazinyl methylene resonances. 
Table 2. Nuclear magnetic resonance data of compound 1.

\begin{tabular}{|c|c|c|c|c|}
\hline \multirow[t]{2}{*}{ C\# } & ppm & $\mathrm{H \#}$ & ppm & Multiplicity \\
\hline & 146.8 & & & \\
\hline & 153.7 & & & \\
\hline & & 5 & 10.8 & $1 \mathrm{H}, \mathrm{br}, \mathrm{s}$ \\
\hline & 147.4 & & & \\
\hline & 138.5 & & & \\
\hline & 124.5 & & & \\
\hline & 38.2 & 10 & 4.27 & $3 \mathrm{H}, \mathrm{s}$ \\
\hline & 27.8 & 11 & 2.94 & $2 \mathrm{H}, \mathrm{t}, J=7.5 \mathrm{~Hz}$ \\
\hline & 22.4 & 12 & 1.87 & $2 \mathrm{H}, \mathrm{m}, J=7.5 \mathrm{~Hz}$ \\
\hline & 14.1 & 13 & 1.08 & $3 \mathrm{H}, \mathrm{t}, J=7.4 \mathrm{~Hz}$ \\
\hline & 129.9 & & & \\
\hline & 132.3 & 15 & 9.14 & $1 \mathrm{H}, \mathrm{d}, J=2.2 \mathrm{~Hz}$ \\
\hline & 120.0 & & & \\
\hline & 132.5 & 17 & 8.15 & $1 \mathrm{H}, \mathrm{dd}, J=8.8,2.4 \mathrm{~Hz}$ \\
\hline & 112.7 & 18 & 7.09 & $1 \mathrm{H}, \mathrm{d}, J=9.0 \mathrm{~Hz}$ \\
\hline & 159.8 & & & \\
\hline & 65.8 & 20 & 4.36 & $2 \mathrm{H}, \mathrm{q}, J=7.0 \mathrm{~Hz}$ \\
\hline & 14.6 & 21 & 1.63 & $3 \mathrm{H}, \mathrm{t}, J=7.0 \mathrm{~Hz}$ \\
\hline & 194.9 & & & \\
\hline & 64.6 & 23 & 3.82 & $2 \mathrm{H}, \mathrm{s}$ \\
\hline 28 & 52.2 & & 2.68 & $4 \mathrm{H}, \mathrm{br}, \mathrm{m}$ \\
\hline, 27 & 52.5 & & 2.54 & $4 \mathrm{H}, \mathrm{br}, \mathrm{m}$ \\
\hline & 53.3 & & 2.41 & $2 \mathrm{H}, \mathrm{q}, J=7.3 \mathrm{~Hz}$ \\
\hline & 11.8 & & 1.05 & $3 \mathrm{H}, \mathrm{t}, J=7.0 \mathrm{~Hz}$ \\
\hline
\end{tabular}

Table 3. Nuclear magnetic resonance data of sildenafil citrate (Badwan et al. 2001).
ppm
$\mathrm{H \#}$
ppm
Multiplicity

131.55

153.56

146.83

146.36

128.65

45.57

27.64

22.15

13.95

124.39

131.00

121.01

138.55

112.90

159.25

65.97

14.43

45.80

53.91

76.69

5

10.83

$1 \mathrm{H}, \mathrm{s}$

24, 28

25, 27

29

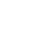

$$
10.83
$$

4.15

2.85

1.78

0.90

$3 \mathrm{H}, \mathrm{s}$

10
11

12

0.90

8.69

$1 \mathrm{H}, \mathrm{d}$

7.73

7.07

$1 \mathrm{H}, \mathrm{d}$

17

$1 \mathrm{H}, \mathrm{d}$

20

4.29

1.56

$2 \mathrm{H}, \mathrm{q}$

21

24, 28

3.03

2.43

2.24

$3 \mathrm{H}, \mathrm{t}$

$4 \mathrm{H}, \mathrm{t}$

$4 \mathrm{H}, \mathrm{t}$

29

$3 \mathrm{H}, \mathrm{s}$ 
Food Additives \& Contaminants, Volume 21, Issue 8 August 2004 , pages 737 - 748

(a)

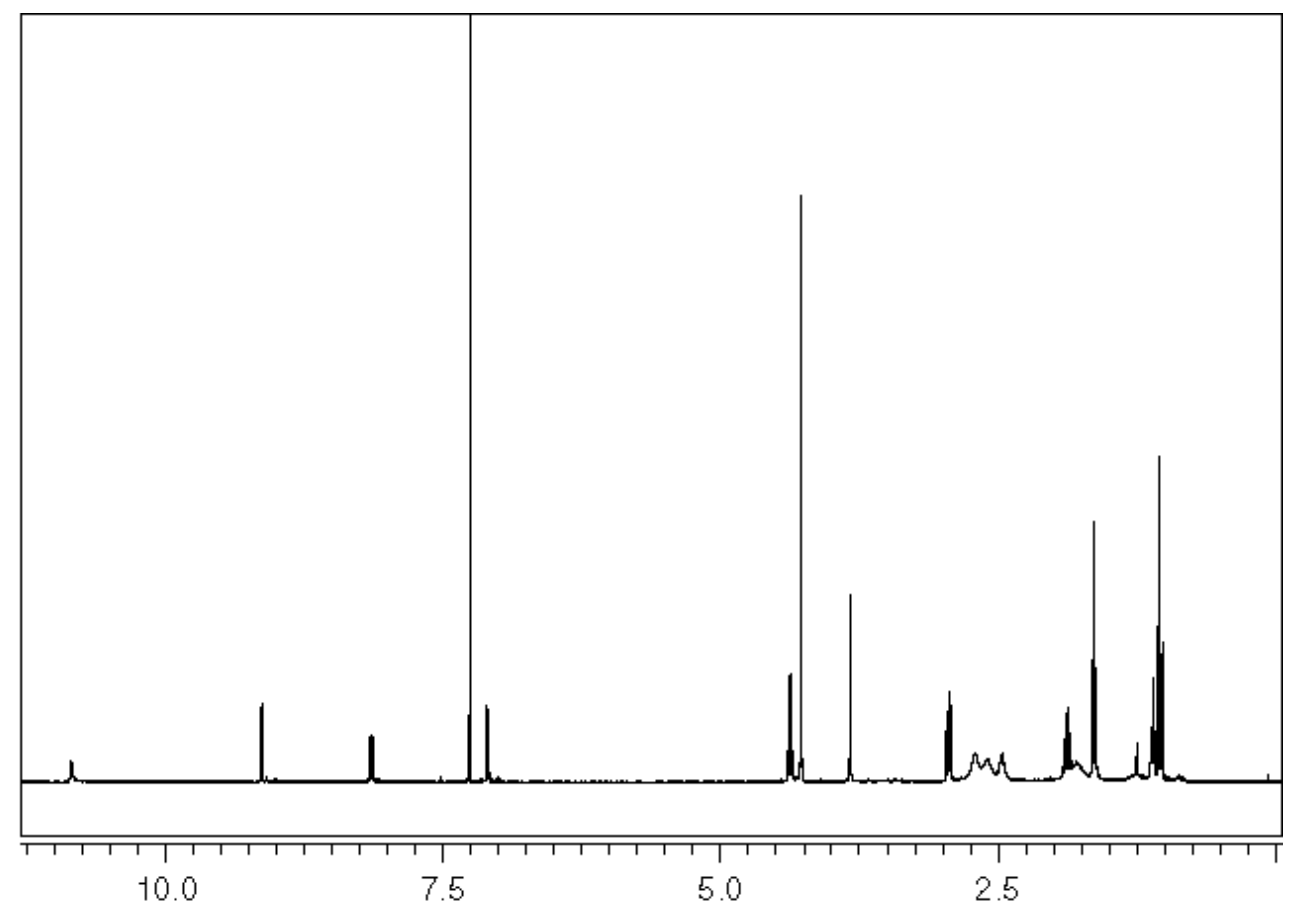

PPM

(b)

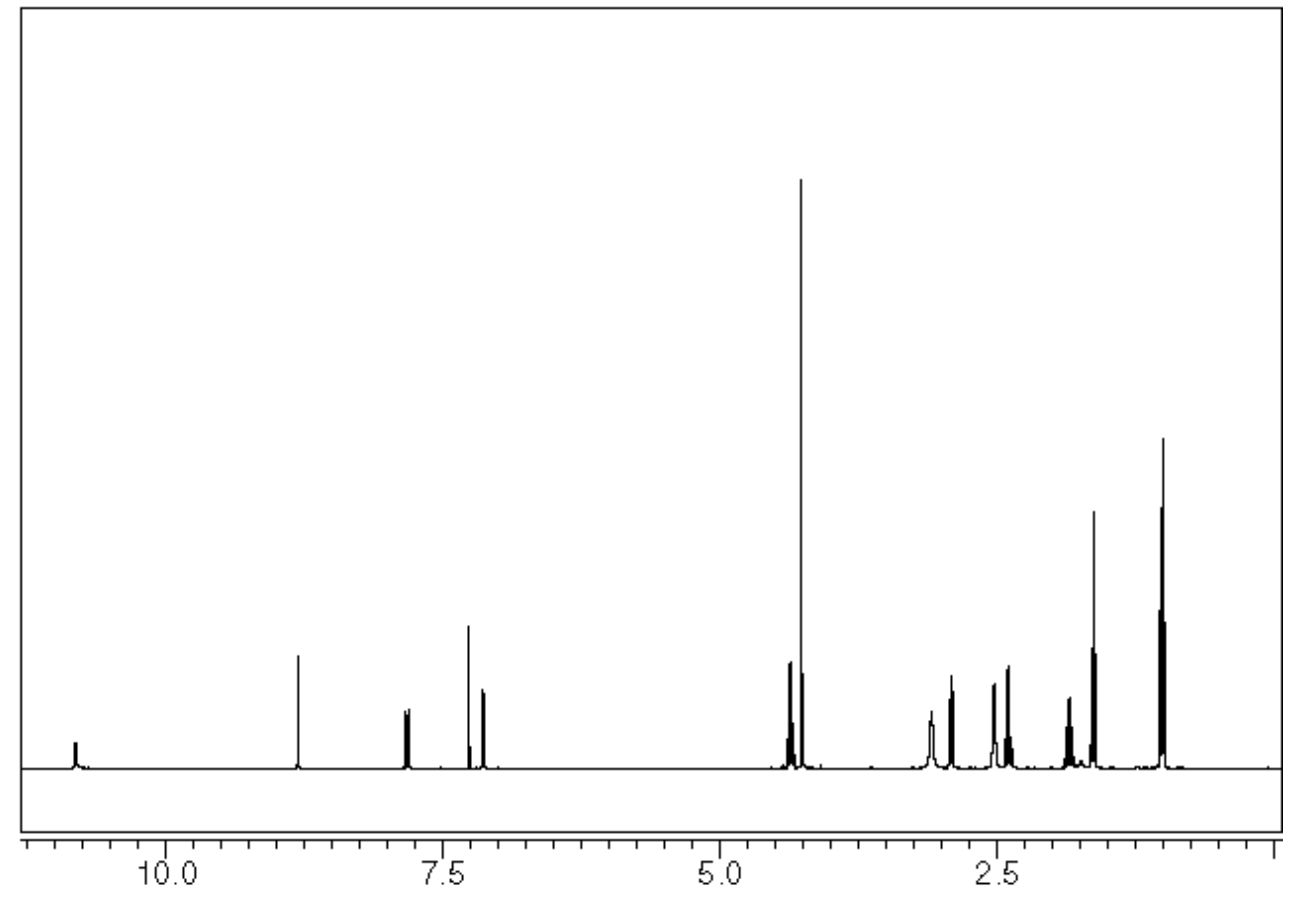

PPM 
(c)

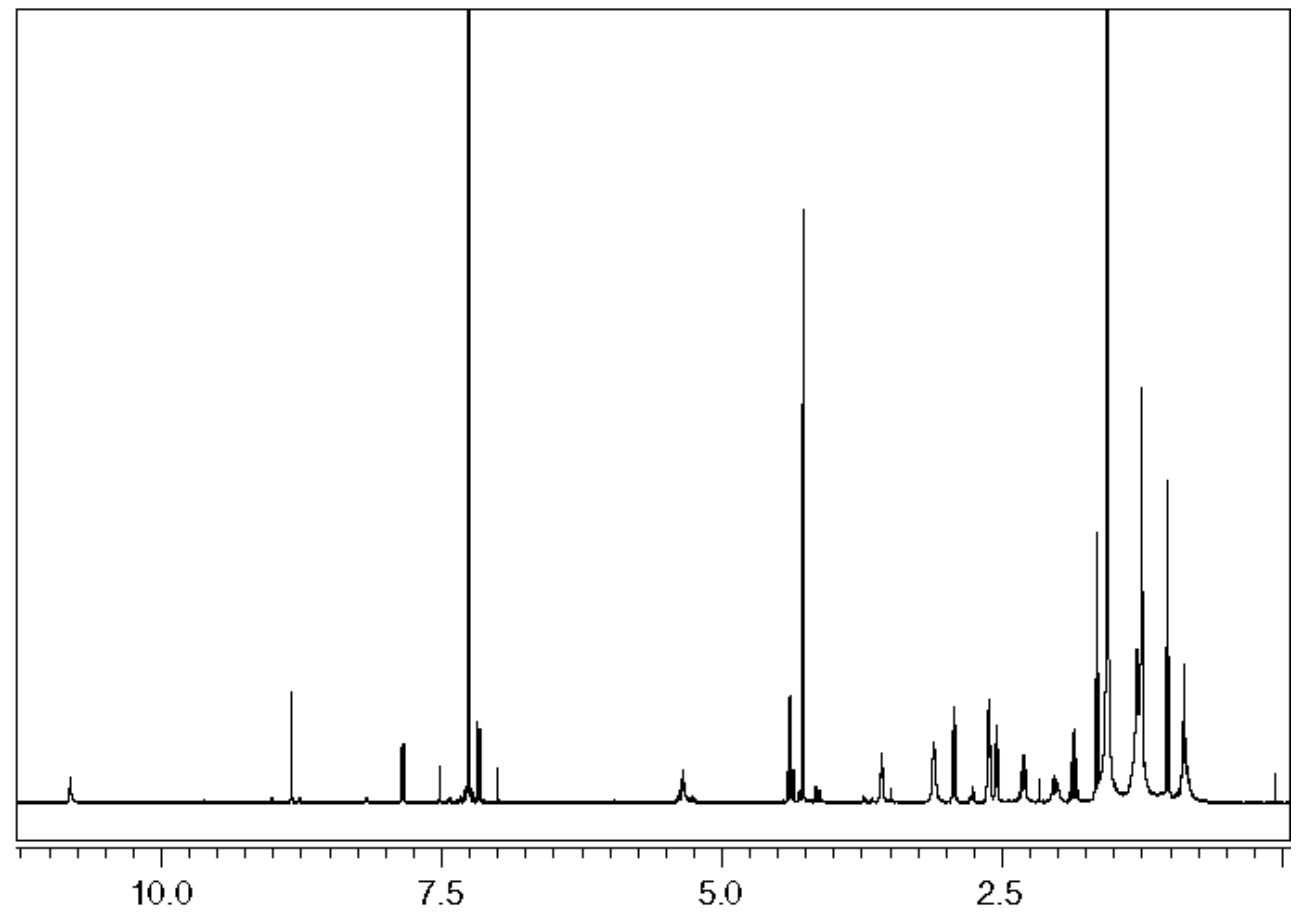

PPM

Figure 3. ${ }^{1} \mathrm{H}$-NMR spectra of unknown compounds: (a) ${ }^{1} \mathrm{H}$-NMR spectrum of 1 in Product $A$, (b) ${ }^{1} \mathrm{H}$-NMR spectrum of 2 in Product $B$, (c) ${ }^{1} \mathrm{H}$-NMR spectrum of $\mathbf{3}$ in Product $\mathrm{C}$.

The ${ }^{13} \mathrm{C}-\mathrm{NMR}$ spectrum shows all the characteristic resonances for a 1 -substituted [3-(6,7dihydro-1-methyl-7-oxo-3-propyl-1H-pyrazolo[4,3- $d$ ]pyrimidin-5-yl)-4-ethoxyphenyl structure element. Compared with sildenafil, the phenyl carbons show minor shifts, which is also indicative of a different substituent. The presence of a ketonic $\mathrm{C}=\mathrm{O}$ is clear from the absorption at $194.9 \mathrm{ppm}$. Quantitative NMR analysis showed that sample A contained approximately $15 \%(\mathrm{w} / \mathrm{w})$ of acetildenafil, which corresponds to $63 \mathrm{mg} / \mathrm{capsule}$.

The IR spectrum shows peaks at 3315, 1697, 1604, 1494, 1393, 1261 and $1030 \mathrm{~cm}^{-1}$. Bands, which could be attributed to a sulphonamide, are absent.

\section{Sample $B$, compound 2}

Based on the LC-ESI-MS ${ }^{n}$ and ${ }^{1} \mathrm{H}$ - and ${ }^{13} \mathrm{C}-\mathrm{NMR}$ data described below, the unknown compound was identified as a sildenafil analogue, in which the $\mathrm{N}$-methylpiperazine moiety is substituted by $\mathrm{N}$-ethylpiperazine (figure 1 ).

Sample B was analysed for sildenafil. Although a peak is observed showing retention time and ultraviolet light spectrum comparable with sildenafil (table 1), the $\mathrm{MS}^{1}$ spectrum does not show an ion at $\mathrm{m} / \mathrm{z}=475$ representing $[\mathrm{M}+\mathrm{H}]^{+}$of sildenafil; however, an ion at $\mathrm{m} / \mathrm{z}=489$ is present. Although this corresponds to the molecular mass of vardenafil, the active substance of Levitra, a relatively new medicine for erectile dysfunction, its retention behaviour on this chromatographic system and ultraviolet light spectrum are different (Bakker et al. 2004).

$\mathrm{MS}^{2}$ spectra of $[\mathrm{M}+\mathrm{H}]^{+}$of sildenafil $(\mathrm{m} / \mathrm{z}=475)$ and of the unknown compound $(\mathrm{m} / \mathrm{z}=489)$ were obtained (figure $2 a, c)$. Both spectra show signals at $m / z=377,313,311$ and 283 . According to the fragmentation pathway proposed by Zhong et al. (2002), these ions lack the piperazine moiety. As the $\mathrm{MS}^{3}$ spectra of $\mathrm{m} / \mathrm{z}=377$ of both compounds are comparable (figure $2 \mathrm{e}, \mathrm{f}$ ), this part of the molecule in both compounds is similar, suggesting that the difference of $14 \mathrm{amu}\left(-\mathrm{CH}_{2}-\right)$ should be in the piperazine moiety. The formation of $\mathrm{m} / z=461$ 
from 489 suggests the loss of $\mathrm{C}_{2} \mathrm{H}_{4}$, indicating the presence of an ethyl group. These findings are consistent with the ${ }^{1} \mathrm{H}$ - and ${ }^{3} \mathrm{C}$-NMR data (figure $3 \mathrm{~b}$ and table 4). These data are in agreement with the data of Shin et al. (2003).

Table 4. Nuclear magnetic resonance data of compound 2.

\begin{tabular}{|c|c|c|c|c|}
\hline C\# & ppm & H\# & ppm & Multiplicity \\
\hline \multicolumn{5}{|c|}{ Atoms in bold show correlation peaks. } \\
\hline 1 & 146.37 & & & \\
\hline 4 & 153.56 & & & \\
\hline & & 5 & 10.81 & $1 \mathrm{H}, \mathrm{bs}$ \\
\hline 6 & 146.86 & & & \\
\hline 8 & 138.28 & & & \\
\hline 9 & 124.39 & & & \\
\hline 10 & 38.12 & 10 & 4.26 & $3 \mathrm{H}, \mathrm{s}$ \\
\hline 11 & 27.65 & 11 & 2.92 & $2 \mathrm{H}, \mathrm{t}, J=7.5 \mathrm{~Hz}$ \\
\hline 12 & 22.16 & 12 & 1.85 & $2 \mathrm{H}, \mathrm{m}, J=7.5 \mathrm{~Hz}$ \\
\hline 13 & 13.95 & 13 & 1.02 & $3 \mathrm{H}, \mathrm{t}, J=7.3 \mathrm{~Hz}$ \\
\hline 14 & 128.57 & & & \\
\hline 15 & 131.08 & 15 & 8.81 & $1 \mathrm{H}$, d. $J=2.4 \mathrm{~Hz}$ \\
\hline 16 & 121.02 & & & \\
\hline 17 & 131.63 & 17 & 7.82 & $1 \mathrm{H}, \mathrm{dd}, J=8.8, J=2.5 \mathrm{~Hz}$ \\
\hline 18 & 112.94 & 18 & 7.13 & $1 \mathrm{H}, \mathrm{d}, J=8.8 \mathrm{~Hz}$ \\
\hline 19 & 159.23 & & & \\
\hline 20 & 65.98 & 20 & 4.36 & $2 \mathrm{H}, \mathrm{q}, J=7 \mathrm{~Hz}$ \\
\hline 21 & 14.44 & 21 & 1.64 & $3 \mathrm{H}, \mathrm{t}, J=7 \mathrm{~Hz}$ \\
\hline 24 & 46.01 & 24 & 3.09 & $4 \mathrm{H}, \mathrm{bs}$ \\
\hline 25 & 51.71 & 25 & 2.53 & $4 \mathrm{H}, \mathrm{bs}$ \\
\hline 29 & 51.80 & 29 & 2.40 & $1 \mathrm{H}, \mathrm{q}, J=7.2 \mathrm{~Hz}$ \\
\hline 30 & 11.85 & 30 & 1.02 & $3 \mathrm{H}, \mathrm{t}, J=7.3 \mathrm{~Hz}$ \\
\hline
\end{tabular}

Based on the PDA total scan chromatogram and the assumption that the extinction coefficient of sildenafil and homosildenafil are comparable, the amount of homosildenafil in sample B was estimated at $142 \mathrm{mg} / \mathrm{tablet}$.

\section{Sample $C$, compound 3}

Based on LC-ESI-MS ${ }^{n}$, direct-infusion ESI-MS ${ }^{n}$, and ${ }^{1} \mathrm{H}$ - and ${ }^{13} \mathrm{C}-\mathrm{NMR}$ data, the compound was identified as a sildenafil analogue bearing an $\mathrm{N}$-hydroxylethylpiperazine moiety instead of an $\mathrm{N}$-methylpiperazine (figure 1).

Sample $\mathbf{C}$ was analysed for PDE5 inhibitors. An abundant peak is observed with a retention time and ultraviolet light spectrum comparable with sildenafil. In de $\mathrm{MS}^{1}$, spectrum peaks are present at $m / z=505,527$ and 543 , indicating $[\mathrm{M}+\mathrm{H}]^{+},[\mathrm{M}+\mathrm{Na}]^{+}$and $[\mathrm{M}+\mathrm{K}]^{+}$for a compound with a molecular mass of 504. The $\mathrm{MS}^{2}$ spectrum of $[\mathrm{M}+\mathrm{H}]^{+}$(figure 2d) shows peaks at $m / z=487$ (loss of $\mathrm{H}_{2} \mathrm{O}$ ), 461 (loss of $\mathrm{CH}_{2}=\mathrm{CHOH}$ ), and $377 . M / z=461$ is also observed in the $\mathrm{MS}^{2}$ spectrum of $\mathrm{m} / \mathrm{z}=489\left([\mathrm{M}+\mathrm{H}]^{+}\right)$of homosildenafil, indicating loss of $\mathrm{CH}_{2}=\mathrm{CH}_{2} \cdot \mathrm{M} / z=377$ is observed in the $\mathrm{MS}^{2}$ spectra of $[\mathrm{M}+\mathrm{H}]^{+}$of sildenafil and homosildenafil, representing the remaining ion after loss of the piperazine moiety. The $\mathrm{MS}^{3}$ spectrum of $\mathrm{m} / \mathrm{z}=505 \rightarrow 377$ from the unknown compound in sample $\mathbf{C}$ obtained by directinfusion ESI-MS (figure 2g) shows resemblance to the $\mathrm{MS}^{3}$ spectra of $\mathrm{m} / z=377$ of sildenafil and homosildenafil. Based on these results, the structure could be hydroxyhomosildenafil. This proposal is supported by the ${ }^{1} \mathrm{H}$ - and ${ }^{13} \mathrm{C}$-NMR data, which are presented in figure $3(\mathrm{c})$ and table 5. 
Table 5. Nuclear magnetic resonance data of compound 3.

\begin{tabular}{|c|c|c|c|c|}
\hline C\# & ppm & $\mathrm{H \#}$ & ppm & Multiplicity \\
\hline \multicolumn{5}{|c|}{ Atoms in bold show correlation peaks. } \\
\hline & \multicolumn{4}{|l|}{146.39} \\
\hline & \multicolumn{4}{|l|}{153.58} \\
\hline & & 5 & 10.81 & $1 \mathrm{H}, \mathrm{bs}$ \\
\hline & \multicolumn{4}{|l|}{146.95} \\
\hline & \multicolumn{4}{|l|}{138.33} \\
\hline & \multicolumn{4}{|l|}{124.46} \\
\hline & 38.22 & 10 & 4.28 & $3 \mathrm{H}, \mathrm{s}$ \\
\hline & 27.71 & 11 & 2.93 & $2 \mathrm{H}, \mathrm{t}, J=7.4 \mathrm{~Hz}$ \\
\hline & 22.23 & 12 & 1.86 & $2 \mathrm{H}, \mathrm{h}, J=7 \mathrm{~Hz}$ \\
\hline & 14.02 & 13 & 1.03 & $3 \mathrm{H}, \mathrm{t}, J=7.3 \mathrm{~Hz}$ \\
\hline & \multicolumn{4}{|l|}{128.82} \\
\hline & 131.13 & 15 & 8.84 & $1 \mathrm{H}, \mathrm{d}, J=2.4 \mathrm{~Hz}$ \\
\hline & \multicolumn{4}{|l|}{121.12} \\
\hline & 131.64 & 17 & 7.84 & $1 \mathrm{H}, \mathrm{dd}, J=8.8, J=2.4 \mathrm{~Hz}$ \\
\hline & 113.07 & 18 & 7.17 & $1 \mathrm{H}, \mathrm{d}, J=8.8 \mathrm{~Hz}$ \\
\hline & \multicolumn{4}{|l|}{159.34} \\
\hline & 66.09 & 20 & 4.39 & $2 \mathrm{H}, \mathrm{q}, J=7 \mathrm{~Hz}$ \\
\hline & 14.52 & 21 & 1.66 & $3 \mathrm{H}, \mathrm{t}, J=7 \mathrm{~Hz}$ \\
\hline 28 & 46.11 & 24,28 & 3.1 & $4 \mathrm{H}, \mathrm{bs}$ \\
\hline 27 & 51.93 & 25,27 & 2.62 & $4 \mathrm{H}, \mathrm{bt}, J=5.4 \mathrm{~Hz}$ \\
\hline & 58.90 & 29 & 2.55 & $2 \mathrm{H}, \mathrm{t}, J=5.4 \mathrm{~Hz}$ \\
\hline & \multirow[t]{2}{*}{57.74} & 30 & 3.58 & $2 \mathrm{H}, \mathrm{t}, J=5.4 \mathrm{~Hz}$ \\
\hline & & $\mathrm{OH}$ & 2.3 & $1 \mathrm{H}, \mathrm{bs}$ \\
\hline
\end{tabular}

Quantitative NMR analysis showed that sample C contained approximately $10 \%(\mathrm{w} / \mathrm{w})$ hydroxyhomosildenafil, which corresponds to $45 \mathrm{mg} /$ capsule.

As three different sildenafil analogues were identified over a short period, it seems there is a tendency towards designer drugs for Viagra counterfeits and herbal aphrodisiacs being distributed on the market. When analysing these products, attention should be given to the possible presence of this type of components. Only screening for the active ingredients of prescription drugs such as sildenafil and vardenafil is not sufficient anymore.

\section{Acknowledgement}

Research was carried out under the authority of the Dutch Health Care Inspectorate and of the Dutch Food and Consumer Product Safety Authority.

\section{References}

1. Badwan, A. A., Nabulsi, L., Al-Omari, M. M., Daraghmeh, N. and Ashour, M. (2001) Sildenafil citrate. Analytical Profiles of Drug Substances and Excipients; Academic Press 27 , p. 339. San Diego - edited by H. G. Brittain

2. Bakker, F., Hartog, K. D., Blok-Tip, L., de Rooij-Lamme, E. K. and de Kaste, D. (2004) Analysis of PDE-5 inhibitors using LC-ESI-MS/MS. - (in preparation)

3. (2004) Concerning the discovery of a so-called health food (non-approved and nonpermitted pharmaceutical) containing sildenafil-like substance (hydroxy homosildenafil). (available at: http://www.mhlw.go.jp/houdou/2004/02/h0213-3.html) (accessed on 13 February 2004). 
Food Additives \& Contaminants, Volume 21, Issue 8 August 2004 , pages 737 - 748

4. Shin, M. -H., Hong, M. -K., Kim, W. -S., Lee, Y. -J. and Jeoung, Y. -C. (2003) Identification of a new analogue of sildenafil added illegally to a functional food marketed for penile erectile dysfunction. Food Additives and Contaminants 20 , pp. 793-796.

5. Zhong, D. F., Xing, J., Zhang, S. Q. and Sun, L. (2002) Study of the electrospray ionization tandem mass spectrometry of sildenafil derivatives. Rapid Communications in Mass Spectrometry 16 , pp. 1836-1843. 